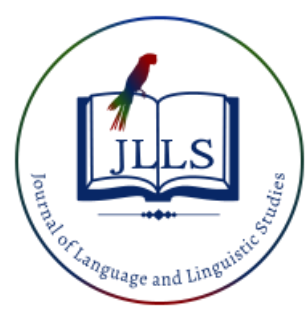

Available online at www.jlls.org

JOURNAL OF LANGUAGE

AND LINGUISTIC STUDIES

ISSN: $1305-578 \mathrm{X}$

Journal of Language and Linguistic Studies, 17(4), 1773-1786; 2021

\title{
Critical condition in Balinese lexicon extinction
}

\author{
I Gusti Ayu Vina Widiadnya Putri ${ }^{\text {al }}$ iD, Wayan Nurita ${ }^{\text {b }}$ iD \\ ${ }^{a, b}$ Universitas Mahasaraswati Denpasar, Bali-Indonesia
}

\section{APA Citation:}

Putri, I.G.A.V \& Nurita, W. (2021). Critical condition in Balinese lexicon extinction. Journal of Language and Linguistic Studies, 17(4), 1773-1786. Doi: 10.52462/jlls. 129

Submission Date:20/02/2021

Acceptance Date:03/05/2021

\begin{abstract}
The impact of the lexicons that were often used in the past will be eroded due to the environmental conditions that surround them. This study has examined the critical condition in Balinese lexicon extinction. There are some Balinese language vocabularies that are almost extinct by the current generation due to cultural hegomonization. The occurrence of capitalist hegemony so it touches a substantial matter in the form of language. This research can inspire language observers and environmentalists as well as the authorities to revitalize the language that has become extinct. The method used in this study is qualitative descriptively by using questioner to collect the data. After analyzing this study, it can be found that some lexicon even extinct since environmental influences. It can erode the existence of the use of some lexicons in society. A new fact found in this study is that the development or change of the Balinese lexicon that occurs is comparative negative historical linguistics which is defined as a genetic change in language and loss of its function and meaning due to the extinction of the ecosystem and its relationship with the environment. The extinction of language due to the environment can be fixed with several efforts that can be made by the community. These efforts are language documenting reviving the oral tradition, stimulating the younger generation to be proud to use Balinese, Input the lexicons in the curriculum content, increase strong commitment from the community to continue using lexicons in their daily communication.
\end{abstract}

Keywords: Critical Condition; Balinese Lexicon; Extinction; Balinese language; Language shift

\section{Introduction}

Language shift is one of the language phenomena that is interesting to study. According to (Holmes, 2001) language shifting or language maintenance can occur in various sectors of life, for example, economy, social, culture, education, politics, government and so on. Language shift concerns the problem of using language by a speaker or a group of speakers which can occur as a result of a shift from one speech community to another (Chaer, 2004). This of course is followed by evidence using language of the speaking community. Awareness of education, improvement in economic conditions, and high population mobility in fact have an effect on the use of language. According to the evidence theory that has been presented language shift and lexicon extinction, there is one interesting thing in this study, in fact the environment is very influential in the language shift. Starting from the theory of language shift that has been initiated, it is found that there are several

\footnotetext{
${ }^{1}$ Corresponding Author

E-mail address: miss.vina@unmas.ac.id
} 
environmental factors that influence language shift. Language shift is no longer only dominated by population movement factors, bilingualism, and generation transfer (intergeneration), however this study found that influenced by the environment is the crucial thing that shifting the language.

Environmental influences can erode the existence of the use of some lexicons in society. Ecology theory explains that Language ecology may be defined as the study of interactions between any given language and its environment (Haugen, 1972). A total of 76 journal publications on Eco linguistics between 1991 and 2015 were analyzed. The diversification of Eco linguistics research has generated some disagreements among researchers regarding the definition of the field. While some researchers prefer a unified view on Eco linguistics, referring it as "the study of the interdependence of language and the perception / interpretation of the natural world we live in", others favor a more topical and surface-oriented definition that keeps the field open-ended. (Chen, 2016). In fact, natural damage, exploitation of nature, natural disasters are not only environmental problems, but can become the biggest problems in the development and existence of language. The language function-based content of the text takes the model dialogue integrating the natural, social and ideological dimensions with the inter-cultural, intra-cultural and trans-cultural contexts into consideration (Tjendani et al., 2019). In the development and civilization of an increasingly developing society, language becomes a means of communication that can maintain the noble values of the nation's culture. However, the times have greatly influenced of human life. As in the globalization theory which has openness to other culture. Oral and ethical behaviours are in fact critical functions of cultural development. One cannot easily separate the functions of cultural development from moral and ethical concerns since the mores and moral elements of a culture are deeply entwined (Ehrich, 2019). Culture is dynamic and can grow and develop following the changing times, because culture is constructed and reconstructed by humans (Larasati, 2018). This alarming rate, which is caused by transnational migration and social mobility, has received increasing attention from society in recent years. As the younger generation are shifting to speak dominant languages, many small communities are facing pressure to safeguard their community languages. The impact caused in the process of globalization is quite influential on human life, such as in the fields of economy, technology, science, etc. (Handarini \& Wulandari, 2020). At the same time, it will disintegrate the existing culture. As a result, that culture will decline or be influenced by other cultures (Syam, 2015).

\subsection{Literature review}

Globalization is physically marked by the development of cities that are part of the world city network. This can be seen from the telecommunications infrastructure, transportation networks, international companies and their branches (Nurhaidah, 2015). The development of the increasingly rapid flow of globalization has caused significant changes to the development of the community. One of the changes that occurred was a change in people's habits. Changing community habits will have an impact on the extinction of old habits that have been abandoned. In Eco linguistic studies, there is a relationship between the environment and changes in living habits with changes in behavior which in turn change the order language used. Previous research that has examined language development which is influenced by the flow of globalization is research from (Ibrahim et al., 2019). This study examines the dominant factors that influence the shift in Lowa's language. There are three social factors that influence the shift in Lowa language, including: (1) gender factor; (2) age factor); (3) Educational Level Factors. The most dominant factor affecting the shift in Lowa language is the age factor. Lowa language is rarely used by children and young people alike, speakers of Lowa are generally older people. This indicates that the Lowa language condition is on the verge of extinction (nearly extinct). Another study on language shifts that lead to the extinction of the mother tongue is research from (Amin \& Suyanto, 2012). The results of this study show a shift in the mother tongue in 
the household realm. Most of the migrants in Semarang City use Indonesian more often than their mother tongue. However, there are some migrants who still retain their mother tongue, namely among traditional migrants who live in village areas. Similar research that has analyzed language shift is research from (Putri, 2018). Based on the results that have been observed in various places in the city of Bandar Lampung, these factors include language loyalty, the concentration of the residential area of speakers, the use of language in the daily traditional realm, the continuity of mother-tongue transition between generations, bilingual patterns, mobility, social, language attitude. Similar research analyzes language shift with regard to social factors such as population movement, bilingualism, social mobility, migrant population, age and education. This research is interesting to study because it analyzes environmental elements and the flow of globalization greatly influences language shift. The language shift that resulted in the extinction of language due to nature and global currents can be found in Balinese. The language change is as well as caused by technological developments and environmental condition change (Suryasa, 2018). Using the correct Balinese language is a measure of the character of an area. However, it cannot be denied that there are some Balinese words that became extinct due to environmental influences in the existence of the use of the Balinese language itself.

\subsection{Research questions}

The environment played a very big role in the extinction of the Balinese language. There is a close gap that in fact the existence of the Balinese language in communication is caused by humans. Meanwhile, the relationship between ecosystems and language is even more critical when it comes to human greed for nature to invest. As a result, a lot of biodiversity was damaged and even could not be saved. As a result of human greed in exploitation of nature and biological resources, various biological damage will occur. Besides, the sociological damage between humans will be disrupted. The extinction of life will destroy the cultural values of society. Due to the loss of culture, the Balinese language will be threatened with extinction. The impact is Balinese lexicon will become extinct along with the elimination of the function and form of the lexicon itself. This research is important to do before the extinction of the Balinese lexicon eroded in greater quantity. This study discusses the rediscovery of Balinese lexicons which are almost not used in communication, explores the reasons why the Balinese language lexicons are extinct or almost not used in communication, then analyzes the impact caused by the extinction of the Balinese lexicons. This research is very important to do immediately because modernization cannot be avoided. As a result, languages will be increasingly eroded and no longer used due to eroded currents of modernization and globalization. Currently, there are many Balinese lexicons that have never been used and have even been forgotten by the community. This study intends to remind readers of the existence of the Balinese lexicons that have been used and known before. In addition, the distribution of questionnaires will be used in this study to determine what factors influence the existence of the Balinese lexicon. So that the lexicon can still be used in public communication. In addition, after being discovered as a result and cause loss of the lexicon, then the public will pay more attention to nature and the environment as a result of language extinction. Previous research has never discussed language shift resulting in extinction due to environmental factors. This study focuses on the extinction of language and its influence by environmental factors. This research is very interesting and different among others, because: 1 . In this study there are some Balinese language vocabularies that are almost extinct and even extinct (not understood) by the current generation due to cultural hegomonization; 2 . The occurrence of capitalist hegemony so it touches a substantial matter in the form of language, 3 . This research can inspire language observers and environmentalists as well as the authorities to revitalize the vocabulary or language that has become extinct so it can re-exist, and 4 . This research will be reference in further research. 


\section{Method}

This research was conducted with a quantitative and qualitative descriptive approach, explaining the reasons, consequences and impacts of the erosion of the existence in using Balinese lexicon which is almost extinct. The interview technique used in this study to determine the extent of environmental influence for the critical existence of lexicons in society. The technique of determining the informants in this article was carried out by purposive sampling. Samples of 44 respondents in several districts in Bali were taken randomly and distributed via WhatsApp to informants who were deemed to meet several criteria, for example, the informants concerned were speakers of Balinese as their mother tongue, were adults and understood language related to nature. This is in accordance with Patton's idea (Satori Djamian, 2013) that the determination of the sample in qualitative research is very appropriate if it is based on research objectives or problems, which use considerations from the researcher, in order to obtain the accuracy and adequacy of the information needed. Data collection techniques used according to (Sugiyono, 2010) which consists of: observation, interviews, and documentation techniques, and literature study. This research uses descriptive-qualitative and interpretative analysis techniques. The data analysis process is carried out by referring to the ideas of Miles and Huberman (Satori Djamian, 2013) which consists of the stages: data reduction, data display, and verification (conclusion drawing / verification).) which is carried out interactively and continues to completion, so that the data reaches saturation.

\section{Result}

Based on the data collected, it can be found that, there are 25 Balinese language lexicon which are almost extinct in the used in society. These 25 words are the lexicon that used in daily by the community, however objects or living things that refer to the word cannot be found nowadays. The Balinese language lexicon is almost extinct due to natural factors that have been eroded by the globalization. People do not use these words since the words are not relevant to use nowadays. Here are 25 endangered words found in environmental contexts in Bali.

Tabel 1. Data Lexicon

\begin{tabular}{cc}
\hline Lexicon & Class Word \\
\hline Bebedag (foal) & verb \\
Geros (Insects like cockroaches) & verb \\
Cilalongan (Kepodang bird) & verb \\
Curik (Bali Starling) & verb \\
Bluang (Stray dogs) & verb \\
Baled (Black insect) & verb \\
Belenging (The kind of insect) & verb \\
Peje peje (Srikantil Bird) & verb \\
Tume (Fleas on clothes) & verb \\
Kotokan (Cocoon) & verb \\
Tengkek (The kind of bird) & verb \\
Prinjak (Ciblek bird) & verb \\
Kapkapan (A kind of squirrel) & verb \\
Sugem (Pergem bird) & verb \\
Pengangon Bojog (Sri Gunting bird) & verb \\
Kerace (Snail in the lake) & verb \\
Nepeng (Traditional rice cooking) & Noun \\
Ngelampit, Metekap (plowing) & Noun \\
Metibuan (Bathing in the river) & Noun \\
\hline
\end{tabular}




\begin{tabular}{cc}
\hline Kayeh (Bathing in the river) & Noun \\
Ngenyat (Divert water in the rice field) & Noun \\
Nebuk (Pounding rice) & Noun \\
Ngudud (Remove plant weeds) & Noun \\
Mekena bubu (instal bubu) & Noun \\
Mekene jeet (Set a rope trap) & Noun \\
\hline
\end{tabular}

Based on the table shown, there are 25 words found in critical condition and rarely used by the public. These words are words that were commonly used in daily life before but cannot be used today. Based on the results of data analysis, it can be stated that these words are increasingly being eroded due to natural conditions and the development of today's society. The factors causing this critical condition are mostly caused by natural exploitation. The exploitation of nature will have a dominant effect on the infrequent use of the lexicon which refers to words related to nature. In addition, Change of Land Function has a strong enough influence on the use of words related to nature. In addition, the lifestyle of people who want to continue to develop can have an influence on the intensity of lexicon use. One of the lifestyles of people who want to continue to grow is the Urbanization program which is carried out independently by the community. Urbanization can have a big impact on the erosion of the words nature used today.

\section{Discussion}

In this part, would be discussed regarding the problem of this study. There are some Balinese language vocabularies that are almost extinct and even extinct (not understood) by the current generation due to cultural hegomonization. It have been clearly analyzed in discussion below.

\subsection{Linguistics Histories Comparative}

Balinese as a communication language has different characteristics. The Balinese language still exists today as the language of communication for the community both in villages and cities. When someone uses Balinese as their introduction to communication, there will be an impression of kinship between someone that used Indonesian in communication. So the Balinese language is still dominantly used in communication, especially communication in customary situations. However, the Balinese language has been eroded by modernization. The Balinese language in its use has been revolutionized from time to time. This revolution led to a shift in the Balinese language, which is closely related to the ecology of language. According to (Haugen, 1972), one of the study spaces for language ecology is comparative historical linguistics. Comparative historical linguistics makes the languages of relatives in a geographic environment the focus of studies to find their genetic historical relations. Below are presented some Balinese lexicons which are almost never used by people in their communication and have evolved into new forms of language along with the times.

Tabel 2. Type of Noun

\begin{tabular}{cc}
\hline Noun & Meaning \\
\hline Bebedag & foal \\
Geros & Insects like cockroaches \\
Cilalongan & Kepodang bird \\
Curik & Bali Starling \\
Bluang & Stray dogs \\
Baled & Black insect \\
Belenging & The kind of insect \\
Peje peje & Srikantil Bird \\
\hline
\end{tabular}




Tume
Kotokan
Tengkek
Prinjak
Kapkapan
Sugem
Pengangon Bojog
Kerace

According to the theory of (Haugen, 1972) in comparative historical linguistics, it is stated that the language in a geographic environment will revolution with the times. Based on the data in the table above, it is stated that there are several Balinese lexicons that have undergone a genetic revolution. The translated Lexicon is a type of noun and verb that is rarely used in communication. Bebedag means foal. The meaning of bebedag in Balinese is not commonly heard because it has been replaced by panak jaran which is translated directly into Balinese, namely anak = panak, Jaran $=k u d a$ (foal). So the word bebedag began to become extinct and was replaced by panak jaran. This is because the word "bebedag" as a foal in daily life is rarely used. Horses were previously used in rural villages for transportation and means of transporting because they can enter the paths in the farmer's garden area. Nowadays, with the transfer of transportation technology since the 90s, horses are rarely used so that there are no horse farms so the word "bebedag" was no longer heard by the next generation. A situation like this has also caused farmers and garden owners to replace horse-drawn vehicles with motorbikes, along with concreting paths for garden "ojek" haul routes. Practically there has also been a shift from dirt trails to ones made of concrete and done independently of the community owners and managers of the gardens. Geros is a type of cockroach-like insect. Along with the times, this animal is difficult to find so the word geros is no longer used. Cilalongan means kepondang bird. The Balinese language of kepondang bird is cilalongan, but this bird is difficult to find both in the city and in the village and along with these conditions the word cilalongan is not widely chaired by people. Other word is Curik. It is a kind of beautiful bird from Bali, a kind of starling, but different from the (Bali Strarling). The Bali White Starling is one of the endangered and endemic animals in Indonesia, precisely in Bali. The word curik is rarely heard because it is replaced by Indonesian with the word Jalak. The population is threatened with extinction. There are not many people know this bird. Several similar words are threatened with extinction along with the extinction of ecosystems and their relationship between living things and their environment. Some of the data above has the same relevance with regard to the uselessness of words in the daily life of Balinese people nowadays. This is due to industrialization, especially "tecnoscape" in the form of western technology which can affect people's activities. It also impacts the language used as a result of globalization. This more precisely creates cultural hegemonization in line with the opinion of Ritzer and Berry Smart. (2012: 927) that economic (capitalistic) globalization is also accompanied by a tendency to homogenize. The violent form is the same as the Americanization of the world - a view that can be found on both the left and the right ideological lines. The economistic conception of globalization occurs relatively simultaneously with the homogenization. However, this does not mean that there is a perfectly equal relationship beyond the existence of a mummy symmetry between those who tend to the heterogenization thesis and the economical conception of globalization.

Tabel 3. Types of Verbs

\begin{tabular}{cc}
\hline Verba & Meaning \\
\hline Nepeng & Traditional rice cooking \\
Ngelampit, Metekap & plowing \\
Metibuan & Bathing in the river
\end{tabular}




Kayeh
Ngenyat
Nebuk
Ngudud
Mekena bubu
Mekene jeet

\author{
Bathing in the river \\ Divert water in the rice field \\ Pounding rice \\ Remove plant weeds \\ instal bubu \\ Set a rope trap
}

Lexicon language will evolve from time to time, however, it cannot be denied that the genetic revolution not only leads to positive changes but has a tendency for negative changes due to changes in the function of the lexicon itself. Some lexicons have lost their true meaning due to changes in the lifestyle of the people. Modernization has been able to change the form of the word that is referred to. Based on the table above, there are several words that have lost their function due to modernization. The word nepeng is a verb which means to traditional cook rice. Along with the times the word nepeng experienced a negative revolution which caused the lexicon to be eroded and no longer used by the community. People are now turning to the use of technology by magic-com. Even magic com has used the villagers along with the electric breakthrough entering the village. For this reason, nepeng activities have begun to be abandoned so that the word nepeng is no longer used by the community. Furthermore, the word ngelampit / metekap is a traditional type of plowing activity. Farmers began to abandon this activity when there was modernization and the ease of using tractors for plowing activities. The word metibuan is a type of verb which means bathing in the river. Bathing in the river is rarely done by the community. The existence of river water pollution with garbage and river water contamination with factory waste has made this activity abandoned. Along with the scarcity of people doing bathing activities in the river, the lexicon is rarely used by the community. Several words that have shifted have been presented in the table with the same characters. So it cannot be denied that the language in the lexicon will disappear due to a negative revolution. Negative revolution in this case is a word that has lost its characteristics and meaning due to changing times or modernization.

Similar to nouns that are rarely used and even extinct, some of the verbs above are also crushed due to technology, which on one side has a negative impact, causing an imbalance in the ecosystem, environmental damage and pollution. The movement of technology from developed countries to developing countries, what is called Technoscapes, is in line with Appadurai's view (Ritzer, 2012) is a global configuration of "technology and the fact that technology, both high and low technology, is both mechanistic and informational, now moving at high speed across various types of boundaries that used to exist. "The movement of this technology is like a double-edged knife, on the one hand as the base of human welfare but on the other hand has caused a lot of damage not only in physical form, but also in psychology.

\subsection{The factors of the Balinese lexicon extinction}

Social life in society can change the form and function of the words used. The impact of the lexicons that were often used in the past will be eroded due to the environmental conditions that surround them. Environmental conditions and people's lives will greatly influence the lexicon revolution. The development of Globalization in Indonesia is felt to be faster, the impact of globalization can be felt in all fields, including security, security and law, economic, social, cultural and political fields (Dewi, 2019). Globalization raises a gap between local and global cultural values. Globalization is something that cannot be avoided by today's society, globalization is able to convince the Indonesian people that liberalism can bring progress and prosperity. (Nurrizka, 2016). The communication system, culture and traditions used by society undergo rapid changes due to changes in global values. The process of globalization has penetrated into people's lives, religions and cultures, 
especially as a result of the increasingly rapid technological advances that are developing in society. The current of globalization is able to change people's lives from classic things to modern ones. However, this does not have a positive impact on language development. The erosion of the language lexicon used by the community can greatly impact the increasingly of globalization. The factors that cause the erosion of the Balinese lexicon in public communication are closely related to the views of the globalization theory:

\subsubsection{Exploitation of nature}

Natural damage is related to ecosystem damage. Due to the flow of globalization, the ecosystem of living things is lost. Ecosystem is a reciprocal relationship between living things and the environment. If the ecosystem has been damaged, it will cause the extinction of living things in the environment. Biotic ecosystems, for example, have a reciprocal relationship between one living thing and another. The place where living things live has been exploited by humans. Forests and nature reserves where living things are rarely found in good condition. The exploitation of protected forests has made the living creatures that live in it extinct. The extinction of these living things had a strong impact on the extinction of language. For example, the Bali starling bird, in the Balinese language it is known as curik. Based on a survey conducted, only $20 \%$ of modern people know clearly what is meant by curik. Some of them have only heard the word curik but have never known clearly where the habitat is curik and how the curik bird is. Nature is also a benchmark for the existence of the lexicon used in society. Language extinction is closely related to the extinction of living ecosystems and their environment. Living things that are homeless will not survive. The insecurity of living things in unfavorable ecosystems results in the extinction of living things. The extinction of living things resulted in the extinction of the registers that followed. So that due to the increasingly rapid flow of globalization, it has a negative impact on ecosystem extinction which is of course followed by language extinction.

Some of the verbs that were used in Balinese daily life, for example: metibuan, ngelampit, ngenyat, nebuk and other words that are rarely even used nowadays, one of the causes is the exploitation of nature as one of the effects of technology coupled with human greed to fulfill libio desires. (Pilliang, 2011) stated that a world surrounded and controlled by libido energy, whose traffic is pleasure traffic, whose economic and social exchange is the exchange of desire, and whose development paradigm is the speed paradigm. This is the economic world and culture of global capitalism, filled with a variety of energies, excitement, movement, change and endless reproduction. Wherever we look, what we see is a variety of articulations of the vibrations of desire, and wherever we walk we find various kinds of libido currents moving unceasingly. Our global world is filled with various movements of libido energy. In open spaces, in rooms, even in remote places, in markets, in government offices, in Super Mall; in a place of discussion, in a place of scientific discussion, even in a holy place the energy of libido always finds its place. Along with the economic, social, and exchange of desire, several new words can be formed, for example we no longer use the word "mek dangin" (a mother who sells tipat cantok in the east of the village) and is replaced with the word "M'ac $d y^{\prime}$ as a style. new life.

The impact of technology to exploit nature which creates a new lifestyle for the community as a reward in the form of "progress" emphasized (Sztompka, 2011), it turns out that progress in one area often occurs in the midst of a setback in other fields. The process of transitioning to the postcommunists in Eastern and Central Europe provides a number of examples. Democratization, the opening of society, the emergence of entrepreneurship and the free market were followed by an increase in unemployment and poverty, the lack of social discipline, an increase in the number of crimes and delinquencies, an uncontrolled struggle for the interests of groups and a flood of cheap mass culture. 


\subsubsection{Change of Land Function}

The land conversion activity carried out by the community causes nature and existing living things to experience an imbalance in the chain of life. Land conversion is a process carried out deliberately by certain parties without thinking about the habitat of living things in it. By changing the land function partially or completely from its actual function to a new desired function, it will have a negative impact on the environment and the potential of the land itself. Several causes of land conversion by certain parties are the result of economic growth. The conversion of land functions due to economic factors has resulted in several areas of land in Bali being gradually converted into building construction which cannot be avoided. The development of the tourism sector in Bali has resulted in the community turning everything into tourist objects and tourism services for tourists. Head of the Production Division of the Bali Food Crops, Horticulture and Plantation Service, I Wayan Sunarta, stated that in 2015 the area of rice farming on the Island of the Gods was 80,063 hectares. However, this area decreased by 537 hectares to 79,526 hectares in 2016. In 2017, the area of rice farming in Bali also became 78,626 hectares, a decrease of 1.13\% compared to last year. The land use conversion activity continues until now. By granting building permits by the local government, green lands are transformed into building construction. This activity is one of the damages to nature and the environment. Generations born during this period will no longer know about rice fields and everything in them. Of course this resulted in the activities carried out by the previous community in the natural environment of rice fields no longer being carried out today. Activities about nature that have been carried out in the past are foreign to the present generation. Some lexicons that are rarely known by the public today, one of which is the word metekap. The word metekap means plowing the fields. As land conversion activities are increasingly being carried out by the community, the word metekap, which is closely related to the natural environment and rice fields, is rarely used. Even the 48 respondents who filled out the survey stated that they never knew the meaning of the word metekap. Only $5 \%$ of them have heard the word metekap but have not understood well what the word means. So that land conversion activities can affect changes in the language of the community. It is not surprising that the loss of several lexicons used in the past was due to land conversion activities that continue to occur today.

When land use change occurs, it will be followed by changes in both physical and non-physical activities and new words will appear and the old ones can no longer be used. This is one of the fundamental factors in the shift of some words so that the next generation does not use them anymore. Seeing the above reality is in line with Appadurai's view (Ritzer and Douglas J Goodman, 2008: 599) that land conversion is related to control of the natural sector to be exploited, occupied, and there is also a flow of capital, power and authority. It involves the process by which "the market, the national stock exchange, and commodity speculation move megamonies across national boundaries at high speed".

\subsubsection{Urbanization}

Choosing the appropriate lexicon entails that the speaker actually possesses the vocabulary necessary for the linguistic interaction, no matter if the situation calls for more or less formal vocabulary (Tocaimaza-Hatch, 2018). Language is the best-suited platform for empirically analysing a society and the relationships within it (Dobrić, 2018). The community use different lexicon when they move to other places. In the process of urbanization, the population generally aims to meet the necessities of life from economic factors (Amin \& Suyanto, 2017). Children in multilingual classes can also learn many languages simultaneously and gain a multilingual identity which will foster their refugee identity (Karanfil \& Demir, 2021). However, one phenomenon that is often overlooked in relation to population migration (who are also language speakers) is the cultural factor, especially regarding language. In Bali, many communities have carried out independent urbanization. The 
highest population movement of the community is from village to Denpasar city. Urbanization occurs because there is no equitable development between rural and urban areas. Most of the people choose to make a living in the city. This results in a reduction in the population in rural areas and conversely the population in cities will be increasingly dense. This will make a change in the trend from an agricultural economy to an industrialist which marks the changing times. This industrialist economic system is attractive for people to move houses from villages to cities.

The community will move because of the new occupancy which provides higher business opportunities. As a result, productive people living in villages are rarely found. The movement of new housing from villages to cities resulted in all activities in the village being abandoned by the community. There was a change in lifestyle from classic to modern. Lifestyle changes made in rural communities who move to cities will be lost and not carried out. Changes the lifestyle have changed due to technological developments offered in urban areas. People started to leave their old habits when they lived in the village. Urban people will begin to adapt to new habits that make their work much easier. Old habits will be left behind and forgotten along with technological developments in the city. One of the activities of rural communities that is often carried out is nepeng. Nepeng is the traditional process of cooking rice. Cooking rice in the way is nepeng often used by villagers on a daily. However, due to the migration of new rural communities to urban settlements, the process of cooking rice in this way is no longer used. The process of cooking rice by the community turns into an electric process using magic com. This change in community habits resulted in a shift in the Balinese lexicon that followed. The word nepeng is no longer known by the younger generation in urban areas because of technological developments that have made them accustomed to cooking rice using magic com. The word Kayeh is also experiencing scarcity in its use. The meaning of the word Kayeh is to bathe in the river. In the past, rivers were the only source of water used for cleaning, bathing, washing and latrines. However, this habit is no longer practiced by the community. Urban rivers have been contaminated with factory waste and garbage. The people's habit of using the river as a place to clean themselves has been abandoned. Along with changes in community habits due to population displacement, the lexicons referred to are no longer used. Based on the survey results, from 48 respondents $77 \%$ of them stated that they had left classic habits and switched to modern habits. Thus, the lexicons that followed have been eroded and extinct.

Urbanization is one Scape most dominant in view (George Ritzer dan Douglas J, 2008) concerning groups or actors mobile (tourists, refugees, guest workers, urban communities) that plays an important role in the shifts in the world in where do we live. It involves actual movement and fantasies about movement. Furthermore, in a world that is constantly changing people cannot let their imaginations sit still for too long and must therefore keep these fantasies alive. Observing Appadurai's view regarding urbanization which requires movement of people, it can be said that with this urbanization there is also a shift in words due to the adaptation of "new" humans to their environment. Humans are social creatures whose main purpose to survive, to socialize both with individuals and their environment.

The extinction of some on vocabulary that has been described above is also closely related to the culture of capitalism as a child of globalization. What is expressed by (Pilliang, 2011) is that if the tendency of the influence of the culture of capitalism continues: a culture of consumerism, a culture of image and spectacle culture, or if the world view built by capitalism on individuals in society is not changed, then in fact the production process Global capitalism is synonymous with the process of destroying local culture, including the language and terms in it. Changing the world view is a fundamental change, in order to revive or revitalize local culture. Changing the world view according to Hazel Henderson in Paradigms in Progress: Life Beyond Economics is by changing the paradigm of social life itself. Local people can no longer depend their future on the paradigm of global capitalism, which worships growth indicators (GNP / GDP) as the only indicators of progress. In the effort to 
revitalize local systems, progress indicators must be developed that are extracted from local systems, which are more in line with local cultural values.

The extinction of some words or vocabulary in Balinese society will also have an impact on the identity of the community itself. The term language indicates the nation, it would be appropriate to see this case. (Adlin, 2006) stated that celebrating the death of identity, by releasing identity from its foundations (genus), is in order to build a space for the development of pure differences in identity, which is called the space of nomadism. Nomadism is the opposite of identity in its conventional sense, namely the tendency to celebrate displacement, rootlessness and pure discontinuity. Nomads do not stop moving from one place to another, so they never live permanently (sedentarity) and have a foundation. In the absence of a foundation, nomads are always moving: changing identities, changing beliefs, exchanging ideologies, changing self-concepts, endlessly. The processes of displacement, transmutation, transposition, deformation and metamorphosis that occur in all fields of nomadology also apply at the semiotic level (sign, code, meaning). Due to the nature of this continual movement, nomads can never have a fixed system. Nomadology is precisely anti-system, anti-foundation, and anti-determination (sendentariness). When identities change endlessly without ever being established, what is created is the death of the identity itself — the death of identity.

\subsection{The Efforts to revitalize the language}

The communication of the sensory experience of the character in shape of traces that the environment leaves on his consciousness avoids intrusion from the position of the privileged speaker even in cases when the lexical choice does not belong to the character (Muhaxheri, 2021; Abu, 2020). The phenomenon of extinction of some of the above words, if not prevented, will get worse along with the flow of globalization. Language as one of the universal elements of culture as a nation needs to be maintained for the survival of its citizens. A culture must have the support of the people, government and academics. This is in line with what (Koentjaraningrat, 2005) stated that in order for a National Culture to be supported by most of the citizens of a country, then as an absolute condition it must be unique and must be proud of the citizens who support it. This is necessary because a national culture must be able to give identity to the citizens of that country. It can also be argued that changes and trends in youth language can affect the general language and result in changes in the general language. Apart from language fashions, changes in language also occur due to changes in the worlds of the speakers of that language (Funda Uzdu Yıldız, 2021). There is another aspect that needs to be considered in developing the National Culture of a country. Another aspect is the requirement that in order for an element of the National Culture to give identity to the citizens of his country, it must be able to create a sense of pride in them, and vice versa, so that it can cause pride in the nation, it must be of high quality.

Several ways to revitalize languages that have become extinct as part of culture, among others:

1. Documentation of extinct and endangered languages,

2. Enabling oral traditions in each language user area,

3. Glocalization in the field of language,

4. Stimulate the younger generation to make them interested in local culture by giving them rewards (awards),

5. The local government should develop a second language learning program for adult age groups. After that, they were encouraged to use the endangered language at home and in public places, 
6. The language that is endangered is included in the curriculum in schools in the area where the language is spoken, and

7. There is a strong commitment from community groups or communities to return in using the language, which is almost extinct.

\section{Conclusions}

Based on the results of the research that has been done, it can be reported that some Balinese lexicons are indeed at a critical period. The results of this study found new facts that natural damage resulted in the loss of lexicons. In one of the study spaces of language ecology, comparative historical linguistics makes the languages of relatives in a geographic environment the focus of study to find their genetic historical relations. These languages develop from time to time and changes. A new fact found in this study is that the development or change of the Balinese lexicon that occurs is comparative negative historical linguistics which is defined as a genetic change in language and loss of its function and meaning due to the extinction of the ecosystem and its relationship with the environment. Several lexicons have been found and have been extinct, so these lexicons became extinct due to the negative revolution. Negative revolution in this case is a word that has lost its characteristics and meaning due to the revolution and modernization. Modernization has had many negative impacts on language development. Some reasons found in this study that led to the extinction of the Balinese lexicon are exploitation, land use change and urbanization. Environmental factors have had many negative impacts on language development. This research finds that environmental damage is one of the reasons for language extinction. So, after finding the causes of the loss of some lexicons, people will pay more attention to nature and the environment as one of the consequences of language extinction. The extinction of language due to the environment can be fixed with several efforts that can be made by the community. These efforts are language documenting reviving the oral tradition, stimulating the younger generation to be proud to use Balinese, Input the lexicons in the curriculum content, increase strong commitment from the community to continue using lexicons in their daily communication.

\section{References}

Adlin, A. (2006). Menggeledah Hasrat. Sebuah Pendekatan Multi Perspektif. Jalasutra.

Amin, M. F., \& Suyanto. (2012). Pergeseran dan Pemertahanan Bahasa. Diglossia, 4(1), 12-17. http://journal.unipdu.ac.id:8080/index.php/diglosia/article/view/226

Amin, M. F., \& Suyanto, S. (2017). Pergeseran dan Pemertahanan Bahasa Ibu Dalam Ranah Rumah Tangga Migran di Kota Semarang. Nusa: Jurnal Ilmu Bahasa Dan Sastra, 12(1), 15. https://doi.org/10.14710/nusa.12.1.15-26

Chaer, A. dan L. A. (2004). Sosiolinguistik: Perkenalan awal. Edisi Revisi. PT. Rineka Cipta.

Chen, S. (2016). Language and ecology: A content analysis of ecolinguistics as an emerging research field. Ampersand, 3, 108-116. https://doi.org/10.1016/j.amper.2016.06.002

Dewi, P. M. (2019). Kajian Tentang Perkembangan Globalisasi Dalam Formulasi Kebijakan Pembangunan Hukum Nasional Indonesia. Juli, 2(1), 42.

Dobrić, N. (2018). Language as a Window into Discrimination: A Corpus Linguistic Analysis of Hatred. The Linguistics Journal, 12(1), 221-238.

Ehrich, J. and R. O. (2019). Morality, Language Use, and Ontogenesis: Vygotsky and Shotter 
Revisited. Linguistics Journal, 13(1), 197-205.

Funda Uzdu Yildız. (2021). Use of Euphemisms in Youth Languae. Journal of Language and Linguistic Studies, 17(2), 1117-1128. http://www.jlls.org/index.php/jlls/article/view/4/5

George Ritzer dan Douglas J. (2008). Teori Sosiologi Modern. Kencana.

Handarini, O. I., \& Wulandari, S. S. (2020). Pembelajaran Daring Sebagai Upaya Study From Home (SFH) Selama Pandemic Covid 19. Family Practice, 8(3), 496-503. https://doi.org/https://journal.unesa.ac.id/index.php/jpap

Haugen, E. (1972). The Ecology of Language. Stanford University Press.

Holmes, J. (2001). An introduction to sociolinguistics. Longman Group.

Ibrahim, I., Ruslan, R., Asnur, M. N. A., Sabata, Y. N., \& Kahar, M. S. (2019). Faktor Sosial Yang Berpengaruh Terhadap Pergeseran Bahasa Lowa. KEMBARA Journal of Scientific Language Literature and Teaching, 5(2), 208. https://doi.org/10.22219/kembara.vol5.no2.208-218

Karanfil, F., \& Demir, S. (2021). Multilingual identity development in a trilingual setting: A case study of refugee identity and language use. Journal of Language and Linguistic Studies, 17(2), 866-883.

Koentjaraningrat. (2005). Kebudayaan Mentalitas dan Pembangunan. PT Gramedia Pustaka.

Larasati, D. (2018). Globalization on Culture and Identity: Pengaruh dan Eksistensi Hallyu (KoreanWave) Versus Westernisasi di Indonesia. Jurnal Hubungan Internasional, 11(1), 109. https://doi.org/10.20473/jhi.v11i1.8749

Muhaxheri, L. T. and N. (2021). Linguistic criticism of the interior monologue in fiction. Journal of $\begin{array}{llll}\text { Language } \quad \text { and } & \text { Linguistic } & \text { 17(2), } & \text { Studies, }\end{array}$ http://www.jlls.org/index.php/jlls/article/view/4/5

Nurhaidah, M. I. M. (2015). Dampak Pengaruh Globalisasi Bagi Kehidupan Bangsa Indonesia. Pesona Dasar (Jurnal Pendidikan Dasar Dan Humaniora), 3(3), 1-14. https://doi.org/10.24815/pear.v7i2.14753

Nurrizka, A. F. (2016). Peran Media Sosial di Era Globalisasi Pada Remaja di Surakarta Suatu Kajian Teoritis dan Praktis Terhadap Remaja dalam Perspektif Perubahan Sosial. Jurnal Analisa Sosiologi, 5(1), 28-37. http://publications.lib.chalmers.se/records/fulltext/245180/245180.pdf\%0Ahttps://hdl.handle.net/2 0.500.12380/245180\%0Ahttp://dx.doi.org/10.1016/j.jsames.2011.03.003\%0Ahttps://doi.org/10.10 16/j.gr.2017.08.001\%0Ahttp://dx.doi.org/10.1016/j.precamres.2014.12

Pilliang, Y. A. (2011). Dunia yang Dilipat, Tamasya Melampaui Batas-Batas Kebudayaan. Matahari.

Putri, N. W. (2018). Pergeseran Bahasa Daerah Lampung Pada Masyarakat Kota Bandar Lampung. Prasasti : Journal of Linguistics, 3(1), 83-97. https://doi.org/10.20961/prasasti.v3i1.16550

Ritzer, G. dan B. S. (2012). Handbook Teori Sosial. Nusa Media.

Satori Djamian, K. A. (2013). Metodologi Penelitian Kualitatif. Alfa Beta.

Sugiyono. (2010). Metode Penelitian Kuantitatif, Kualitatif, dan R\&D. Alfa beta.

Suryasa, I. W. (2018). Language maintenance of Balinese vocabulary in agriculture. International Journal of Linguistics, Literature, and Culture, 4(4), 38-43. https://doi.org/10.21744/ijllc.v4n4.258 
Abu Rabiah, E. (2020). Lexical measures for testing progress in Hebrew as Arab students' L2. Journal of Language and Linguistic Studies, 16(3), 1096-1114. Doi: 10.17263/jlls.803551

Syam, H. M. (2015). Kalangan Remaja Kota Banda Aceh. Jurnal Ilmu Komunikasi, 3(1), 54-70.

Sztompka, P. (2011). Sosiologi Perubahan Sosial. Prenada Media Group.

Tjendani, E. N., Suastra, I. M., Mbete, A. M., \& Seri Malini, N. L. N. (2019). An Ecolinguistics Perspectives For English Syllabus Development. E-Journal of Linguistics, 13(2), 249. https://doi.org/10.24843/e-j1.2019.v13.i02.p06

Tocaimaza-Hatch, C. C. (2018). A Comparison of Formal Register through Lexical Choices in Heritage and Second Language Speakers of Spanish, 12(1), 70-96.

\section{AUTHOR BIODATA}

I Gusti Ayu Vina Widiadnya Putri, S.S, M.Hum was born in Denpasar on January 15, 1988. The author completed his undergraduate education at Warmadewa University by taking English Literature studies, especially in Sociolinguistics and completed his Masters Education at Udayana University by taking in Linguistics. Currently the author is a lecturer at the English Literature Study Program, Faculty of Foreign Languages, Mahasaraswati University Denpasar. The author started a career in the world of education since 2009 until now. As a teacher, the writer must continue to learn. Continuing to learn relentlessly has finally become the author's motto to keep working. The authors' works are then published in various national and international scientific journals. Several studies have been funded by the Institute and the Ministry of Research, Technology and Higher Education by participating in research grants, both internal and national grants. The author's area of interest is the study of Applied Linguistics and English for Tourism. Until now the author has produced various types of Linguistics and Tourism study books that are used as references by students and researchers.

Dr. Wayan Nurita, S.S., M.Si was born in the village of Wanagiri-Buleleng on May 16, 1968. He is currently a lecturer in Japanese at the Japanese Literature Study Program, Faculty of Foreign Languages, Mahasaraswati University Denpasar. Prior to becoming a lecturer, 15 years in the hospitality sector as Front Office staff at the Bali Hilton International Nusa Dua Bali, from Bellman workedto Assistant Japanese Guest Relation Manager (Wa No Kutsurogi). Was sent from Hilton to attend Managerial Training at Nagoya Hilton International in 1997. From 1989 to 1990 he studied at BPLP (Bali Tourism Education and Training Center) which is now STP Nusa Dua Bali. From 2001 to 2004, he studied Diploma III at the Academy of Foreign Languages (ABA) Saraswati Denpasar, then from 2006 to 2008 at S1 Japanese at STIBA Saraswati Denpasar. In 2009 he continued his Masters in Cultural Studies at Udayana University. From 2012 to 2014 he studied at the Faculty of Law, Warmadewa University. In 2017 he completed his Doctoral Degree in Cultural Studies at Udayana University, especially Japanese Cultural Studies. The author is active in organizations engaged in martial arts, currently the Chair of Bali Aikikai since 2019. The author is also an apprenticeship consultant to Japan between the Manpower Office of Buleleng Regency and Tsukuba Chikusan Jigyou Kyoudou Kumiai. Apart from being busy as a teacher and consultant, he is also engaged in the plantation business. Awards have been won, such as being the First Winner of the National 2004 and representing Indonesia at the Japanese Speech Contest Asean Japanese Speech Contest inin Tokyo, Japan. Award by the Manpower Office of Buleleng Regency as a Japanese language instructor in 2017. 